\title{
Dört Yaşlı Erkek Bir Kedide Nekrotik Glossitis Olgusu
}

\author{
Fatih HATİPOĞLU ${ }^{1,2 a *}$ Abuzer TAŞ ${ }^{3,4 b}$ İsmail ŞEN ${ }^{5 c}$ Aiperi AİTMYRZA KYZY ${ }^{4 d}$ \\ Nur ABDIMANAP UULU ${ }^{5 e}$
}

\author{
${ }^{1}$ Selçuk Üniversitesi, Veteriner Fakültesi, Patoloji Anabilim Dalı, Konya, TÜRKIYE \\ ${ }^{2}$ Kırgızistan-Türkiye Manas Üniversitesi, Veteriner Fakültesi, Patoloji Anabilim Dalı, Bişkek, KIRGIZISTAN \\ ${ }^{3}$ Van Yüzüncü Y1l Üniversitesi, Veteriner Fakültesi, Cerrahi Anabilim Dalı, Van, TÜRKIYYE \\ ${ }^{4}$ Kırgızistan-Türkiye Manas Üniversitesi Veteriner Fakültesi, Cerrahi Anabilim Dalı, Bişkek, KIRGIZISTAN \\ ${ }^{5}$ Kırgızistan-Türkiye Manas Üniversitesi, Veteriner Fakültesi, İç Hastalıkları Anabilim Dalı, Bişkek, KIRGIZISTAN \\ ${ }^{a}$ https://orcid.org/0000-0002-0103-5868, ${ }^{b}$ https://orcid.org/0000-0002-7326-1768 \\ chttps://orcid.org/0000-0002-2965-7183, ${ }^{d}$ https://orcid.org/0000-0003-3363-0941 \\ ${ }^{e}$ https://orcid.org/0000-0001-6814-4842
}

*Sorumlu yazar: fhatip@selcuk.edu.tr, fatih.hatipoglu@manas.edu.kg

\section{Ö Z E T}

Dört yaşlı erkek melez bir kedide dilin dorsalinden alınan bir kitlede nekrotik glossitis olgusu tanımlandı. Yaklaşık 1.5 sene önce dilde bir kitle nedeniyle operasyon yapıldığı bildirildi. 1 ay öncesinde ise kedinin yemek yerken ağızdan fazla miktarda salya ve bazen de kan geldiğinin gözlenmesi üzerine hayvan sahibi tarafindan dilde bir kitle oluşumu fark edilmiş ve kedinin muayenesi Kırgızistan-Türkiye Manas Üniversitesi Veteriner Fakültesi Kliniğinde yapılmıştır. Yapılan muayenede, gıda alımını ve yutkunmayı kısmen engelleyecek şekilde dilin kaudal bölgesinde ve dorsal yüzeyinden taşkın görünümde bir kitle gözlendi ve bu kitlenin operasyonla alınmasına karar verildi. Kitle sağlam doku aleyhine elektrokoter ile ekstirpe edildi. Alınan kitle Patoloji Laboratuvarına gönderildi. Kitle, 1,2×1,5x2 cm ebatlarında ve sert kıvamdaydı. Kitlenin yüzeyinde yer yer eroziv-ülseratif alanlar gözlendi. Kesit yüzünde ise 2-3 mm çapında sarımsı-gri renkte odaklar dikkati çekti. Mikroskobik incelemelerde; epitel hücrelerindeki dejenerasyon, nekroz ve deskuamasyon sonucu oluşan erozyon ve ülserler gözlendi. Bu alanlarda propriyada çoğunluğu nörtofil granülositlerden oluşan yangısel hücreler ile bağ doku artışları dikkati çekti. Dil kasları arasına serpilmiş olarak farklı büyüklüklerde pembe renkte nekrotik odaklar ile bu odakların çevresinde yangı hücrelerinden oluşan bir kuşak ve bağ doku artışları gözlendi. Sunulan olguda, tümör şüphesiyle alınan kitlede nekrozlarla birlikte gözlenen değişiklikler sonucunda nekrotik glossitis tanısı konmuştur. Ülserli ve kanamalı görünümde olan kitleler genellikle tümöral oluşumlar olarak yorumlanır. Ancak bu olguda da görüldüğü gibi tümör olarak değerlendirilen benzer görünümdeki kitlelerde nekrotik- yangısel değişikliklerin de dikkate alınması gerektiği kanısına varılmıştır. Benzeri durumlar için klinisyenlerin konuya dikkatini çekmek ve veteriner hekimliğe katkı sağlanması amacıyla olgunun sunulması uygun bulunmuştur.
MAKALE B İLG ÍS İ

Olgu sunumu

Gelis : 11.10.2021

Kabul: 10.11.2021

Anahtar kelimeler: Kedi, nekrotik glossitis, patoloji, cerrahi

\section{A Case of Necrotic Glossitis in a Four Years-Old Male Cat}

\section{A B S T R A C T}

In this presentation, a case of necrotic glossitis was described in a mass removed from the tongue in a 4-year-old male crossbred cat. One month ago, when the cat was eating a large amount of saliva and sometimes blood was observed from the mouth, a mass formation on the tongue was noticed by the animal owner. Cat's inspection was performed in Kyrgyzstan-Turkey Manas University, Faculty of Veterinary Medicine Clinics. In the inspection, a bulging mass was observed in the caudal region and dorsal surface of the tongue, partially preventing food intake and swallowing. The animal's mouth was opened properly. The tongue pulled out. The mass was extirpated against intact tissue with electrocautery. The extracted mass was sent to the Pathology Laboratory. The mass was $1.2 \times 1.5 \times 2 \mathrm{~cm}$ in size and had a firm consistency. Partly erosive-ulcerative areas were observed on the surface of the mass. Yellowish-gray foci with a diameter of 2-3 mm were noticed on the cut surface. In microscopic examinations; erosion and ulcers in epithelial layer, inflammatory cells and increased connective tissue were noted in propria. Pink necrotic foci of different sizes scattered between the tongue muscles, a band of inflammatory cells and an increase in connective tissue around these foci were observed. In the presented case, a diagnosis of necrotic glossitis was made as a result of the changes observed with necrosis in the mass taken with suspicion of tumor. Masses with ulcerated and bleeding appearance are generally interpreted as tumoral formations. However, as observed in this case, it was concluded that necrotic-inflammatory changes should also be taken into account in masses with similar appearance that are evaluated as a tumor. For similar situations, it was deemed appropriate to present the case in order to draw the attention of clinicians to the subject and to contribute to veterinary medicine.

$\underline{\text { ARTICLE INFO }}$

Case report

Received: 11.10 .2021

Accepted: 10.11.2021

Keywords:

cat, necrotic glossitis, pathology, surgery

To Cite: $\quad$ Hatipoğlu F, Taş A, Şen İ, Aitmyrza KA, Abdımanap UN 2021. Dört Yaşlı Erkek Bir Kedide Nekrotik Glossitis Olgusu. MJAVL Sciences. 11 (2) 208-213. 


\section{GİRIș}

Ağız dokularının yangısı birincil veya ikincil olabilir ve etkilenen bölgeye göre farklı isimlendirmeler kullanılmaktadır. Diş etinin yangısı gingivitis, dudağınki şeilitis, periodontiyumun nongingival dokularınınki periodontitis, ağız mukozasınınki stomatitis, dorsal veya ventral dil yüzeyinin mukozasınınki glossitis, damak mukozasınınki palatitis ve farinks mukozasın farenjit olarak isimlendirilmektedir (Görgül ve ark. 2012, Reiter 2014, Uzal ve ark. 2016).

Ağız mukozası bazı özellikleri ile mikrobiyal invazyonlara oldukça dayanıklıdır. Bu özellikler; skuamöz mukozal örtü yani kutan mukoza ile örtülü olması, ağız bölgesinin lenforetikuler doku yönünden zengin olmasına ilgili oral sekresyonda fazla miktarda immunoglobulinlerin bulunması, submukozanın yangısel hücrelerden zengin olması ve tükürüğün antibakteriyel özelliği şekilde sıralanabilir (Çiftçi ve ark, 2021, Gelberg 2012, Uzal ve ark. 2016). Ağız boşluğunun mikrobiyal florası hem kendi arasında, hem de konakçı ile uyum içerisindedir. Bu dengeyi ve uyumu bozan, sistemik hastalıklar, stres faktörleri, beslenme ve hücresel dengesizlikler ile tükürüğün bileşiminin, pH'sının ve miktarının bozulması stomatitis için predispoze faktörlerdir (Çiftçi ve ark, 2021). Ağız boşluğu yangıları; irkiltici, yakıcı kimyasal bileşiklerin etkisi ile superfisyal (yüzeysel), ya da nekrobasilloz gibi bakteriyel etkenlere ilgili profund (derin) olabilirler (Çiftçi ve ark, 2021, Uzal ve ark. 2016).

Lezyonların doğası ve şiddeti, hastalığın etiyolojisine ve süresine bağlı olarak büyük ölçüde değişir. Oral yangısel koşulların diğer nedenleri arasında immünopati (örn., otoimmün hastalık, immün yetmezlik), kimyasal ajanlar, enfeksiyöz hastalıklar, travma, metabolik hastalıklar, gelişimsel anomaliler ile tahrişe veya iltihaplanmaya, yanıklara, radyasyon tedavisine veya neoplaziye yatkınlık oluşturan yapısal anatomi sayılabilir. Oral enflamasyon, glossitis, stomatitis ve oral ülserasyonlarla ilişkilendirilen bulaşıcı ajanlar arasında kedi herpesvirüsü, kedi calicivirüsü, kedi lösemi virüsü, kedi immün yetmezlik virüsü, köpek gençlik hastalığı virüsü, Bartonella henselae ve bazı Leptospira serovarları bulunur (Reiter 2014, Uzal ve ark. 2016). Ağız mukozasındaki özellikle ülseratif lezyonlar, piyojenik bakterilerin ve çoğunlukla oral floranın bağ dokuya veya kas dokusuna kadar yayılmasına neden olabilir. Buna ilgili olarak dudaklar, dil, yanak, yumuşak damak ve farinkste purulent yangı veya irinin doku arasına yayılması sonucu selulitis gelişir. Ağız mukozasında apseler ile mukoza veya deriye açılan fistuller şekillenebilir. Ağız boşluğundaki epitel tabakasının derin nekrozu ile birlikte olan nekrotik stomatitis daha çok termik ve kimyasal etkiler sonucu oluşur. Ancak hayvanlarda profund stomatitislere daha çok Fusobacterium $(F)$ necrophorum ve diğer anaerop bakteriler neden olurlar (Çiftçi ve ark, 2021, Uzal ve ark. 2016).

\section{MATERYAL VE METOT}

\section{Olgunun Tanımı}

Dört yaşlı erkek melez bir kediye yaklaşık 1.5 sene önce dilde bir kitle nedeniyle operasyon yapıldığı bildirildi. 1 ay öncesinde ise kedinin yemek yerken ağızdan fazla miktarda salya ve bazen de kan geldiğinin gözlenmesi üzerine hayvan sahibi tarafından dilde bir kitle oluşumu fark edilerek muayene için Kırgızistan-Türkiye Manas Üniversitesi Veteriner Fakültesi Kliniğine getirildi. Yapılan muayenede, gıda alımını ve yutkunmayı kısmen engelleyecek şekilde dilin kaudal bölgesinde ve dorsal yüzeyinden taşkın görünümde bir kitle gözlendi (Resim 1A) ve bu kitlenin operasyonla alınmasına karar verildi. Operasyon için Xylasine hidroklorür (1cc/10 kg) ve ketamin hidroklorür (10 $\mathrm{mg} / \mathrm{kg}$ ) verilerek anesteziye alındı. Hayvanın ağzı uygun şekilde açıldı ve dil dışarı doğru çekildi. Kitle sağlam doku aleyhine elektrokoter ile ekstirpe edildi (Resim 1B). Post operatif bakımı yapıldı 

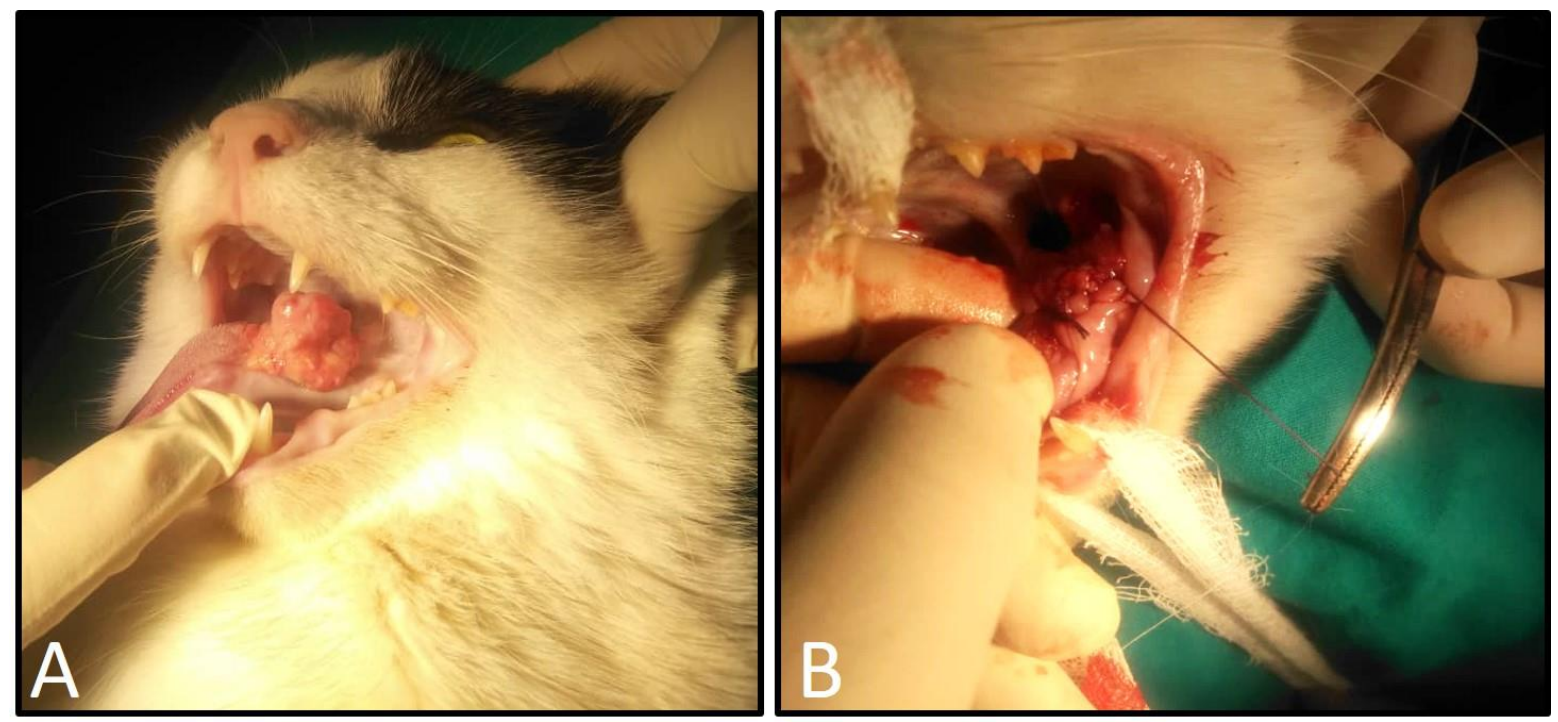

Şekil 1. A. Dilin kaudal bölgesinde ve dorsal yüzeyinden taşkın görünümdeki kitle, B. Kitlenin operasyonla ekstirpasyonu

Alınan kitle inceleme yapılması için Patoloji Laboratuvarına gönderildi. Kitle, 1,2x1,5x2 cm ebatlarında ve sert kıvamdaydı. Kitlenin ağız boşluğuna bakan yüzeyinde yer yer eroziv-ülseratif alanlar gözlendi (Resim 2A). Kesit yüzünde ise 2-3 mm çapında sarımsı-gri renkte odaklar dikkati çekti (Resim 2B). Mikroskobik incelemelerde; epitel hücrelerindeki dejenerasyon, nekroz ve deskuamasyon sonucu oluşan erozyon ve ülserler gözlendi. Bu alanlarda propriyada çoğunluğu nörtofil granülositlerden oluşan yangısel hücreler ile bağ doku artışları dikkati çekti (Resim 3A). Dil kasları arasına serpilmiş olarak farklı büyüklüklerde pembe renkte nekrotik odaklar ile bu odakların çevresinde yangı hücrelerinden oluşan bir kuşak ve bağ doku artışları gözlendi (Resim 3.B,C).
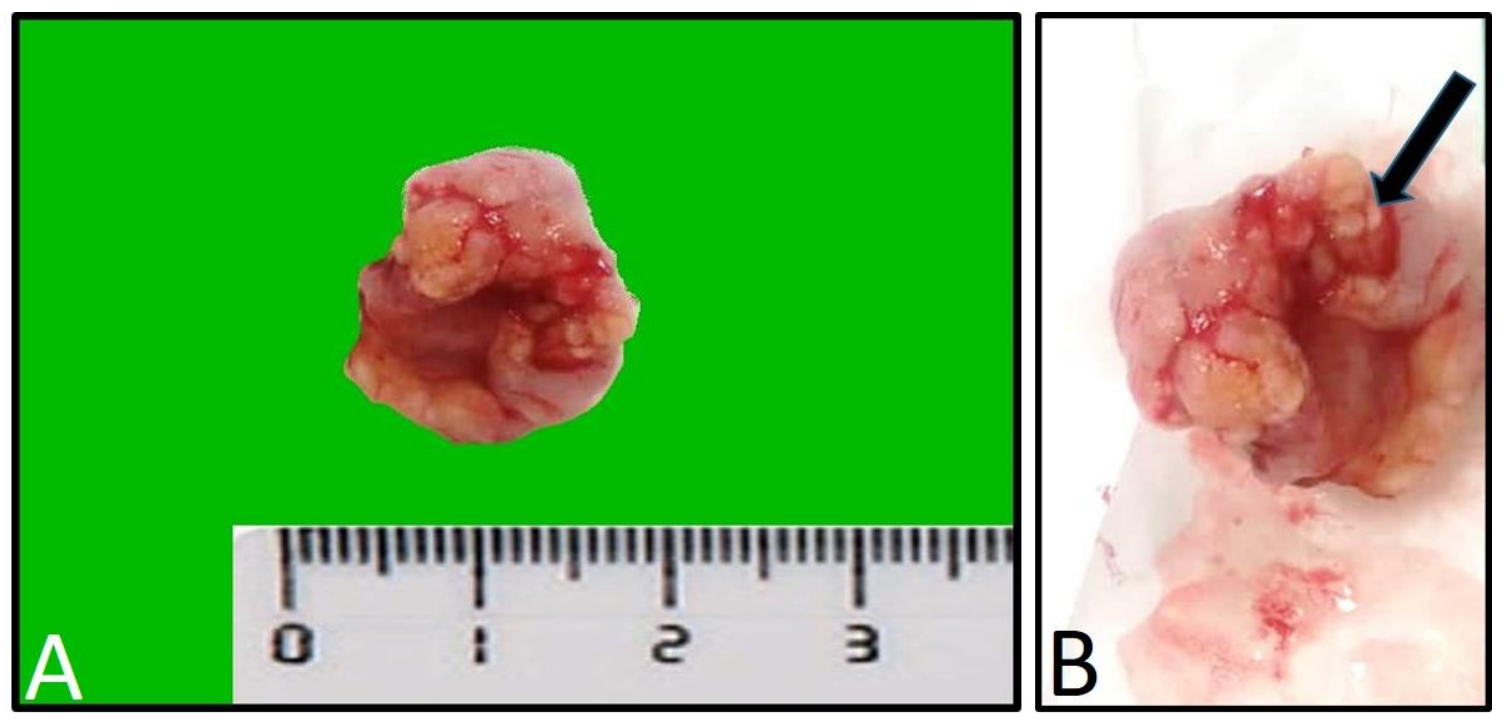

Şekil 2. A. Sert kıvamlı kitlenin yüzeyinde yer yer eroziv-ülseratif alanlar, B. Kesit yüzünde ise 2-3 mm çapında sarımsı-gri renkte odaklar (ok). 


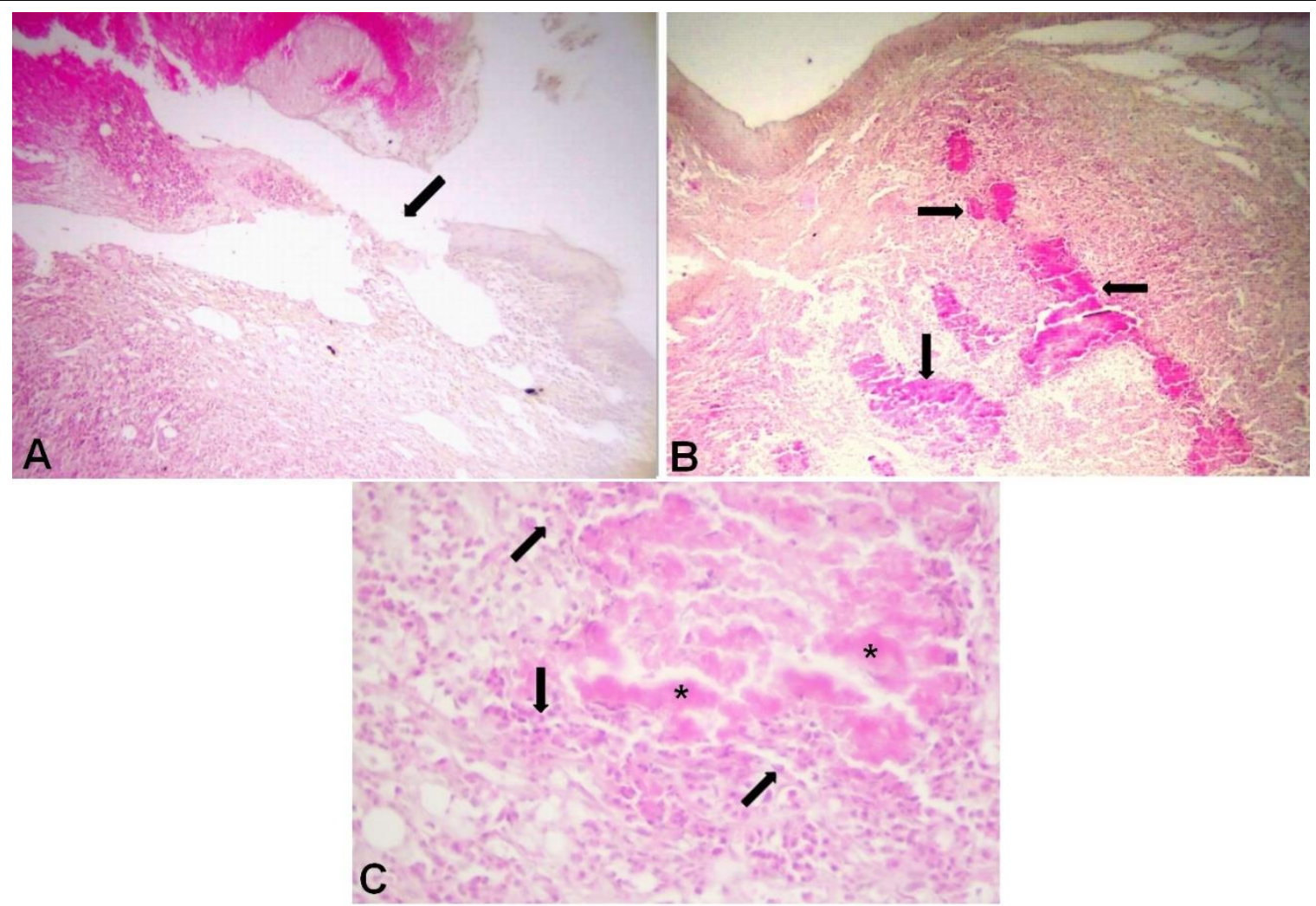

Şekil 3. A. Epitel hücrelerindeki dejenerasyon, nekroz ve deskuamasyon (ok) sonucu oluşan erozyon ve ülserler, propriyada çoğunluğu nörtofil granülositlerden oluşan yangısel hücreler ile bağ doku artışları. H\&Ex100, B. Dil kasları arasına serpilmiş olarak farklı büyüklüklerde pembe renkte nekrotik odaklar (oklar) ile bu odakların çevresinde yangı hücrelerinden oluşan kuşak ve bağ doku artışları, H\&Ex40, C. Pembe renkte nekrotik odaklar (*) ile bu odakların çevresinde yangı hücreleri (oklar), H\&Ex400.

\section{BULGULAR VE TARTIŞMA}

Dilin akut veya kronik bir yangısı olan glossitis; bulaşıcı (kalisivirüs, herpesvirüs, rinotrakeit virüsü, leptospiroz) veya fiziksel (taş fazlalığı ve periodontal hastalıktan kaynaklanan tahriş, dilin altına giren veya yerleşen yabancı cisimler, travmatik yaralar) nedenlerle oluşabilir. Ayrıca kimyasal maddeler, metabolik hastalıklar (üremi, hipoparatiroidizm, diyabet), elektrik veya termal yanıklar ve böcek sokmaları gibi diğer nedenlerle oluşabildiği gibi, yabancı cisim glossitisi, özellikle tüylerinden bitki çapaklarını çıkarmaya çalışan uzun tüylü köpeklerde bir sorundur (Görgül ve ark. 2012,Reiter 2014, Uzal ve ark. 2016).

Travmatik stomatitisler, ağız mukazasına gömülü bitki kalıntıları-kıymıkları veya fiberglas izolasyonu sonrasında görülebilir. Dieffenbachia türü bitkiler çiğnendiğinde ağızda yangı ve ülserlere de neden olabilir. Kese tırtıllarıyla temas da şiddetli glossitise neden olabilir. Bunların yanı sıra üremi de stomatitis ve oral ülserler oluşturabilir (Anderson ve ark 2017, Reiter 2014, Uzal ve ark. 2016).

Kedilerin ülseratif stomatitisi ve glossitisi veya lenfositik-plazmasitik stomatitisi, boğaz mukozasının, kommisura ve daha az yaygın olarak sert damak, diş eti ve dilin ülseratif ve kronik bir yangısıdır. Bu sendrom yaşlı kedilerde daha sık görülür ve periodontitise eşlik edebilir. Sebep bilinmemekle birlikte, Gram-negatif anaeroblar ve spiroketlerin baskınlığı ile oral mikrobiyotadaki dengesizliği içeren, inflamatuar lezyon bölgelerinde mikrobiyal çeşitlilikte genel bir azalmaya yol açan sebepler gibi birçok faktörün etkisiyle oluşmaktadır. Kedi plazma hücreli gingivitis-farenjitisi veya kedi kronik gingivostomatitisi, esas olarak glossopalatin kemerlerde, kaudal olarak palatofaringeal kemere ve rostral olarak gingivaya uzanan kabarı eritematöz, proliferatif lezyonlarla karakterizedir (Gracis 2015, Uzal ve ark. 2016). Eozinofilik ülser (eozinofilik granülom, yalama granülomu, labiyal ülser, kemirgen ülseri), her yaştan kedide dudakların mukokutanöz bağlantılarının ve daha az ölçüde oral mukoza ve derinin kronik, yüzeysel ülseratif bir lezyonudur. Hastalığın nedeni bilinmemekte, fakat alerjik hastalık ve birincil eozinofil disfonksiyonu dahil olmak üzere bir çok etiyolojiden bahsedilmektedir (Uzal ve ark. 2016).

Ağız mukozasındaki lezyonlar, genellikle normal ağız florasında olan piyojenik bakterilerin submukoza ve kasın bağ dokularına girmesine izin verebilir ve bu durumda derin stomatitisler oluşur. Dudaklarda, dilde, yanakta, yumuşak 
damakta ve farinkste purulent yangı veya selülit gelişebilir. Epitel ve lamina propriada basit nekrozla karakterize nekrotik stomatitise, termal veya kimyasal ajanlar neden olabilir. Hayvanlarda genellikle $F$. necrophorum ve diğer anaeroblardan kaynaklanır (Nagaraja ve ark, 2005,Uzal ve ark. 2016).

F. necrophorum çeşitli ekzotoksinler ve endotoksinler üretir. Endotoksinler içerisinde lökosidinler, hemolizinler ve sitoplazmik toksin bulunur ve bunların tümü muhtemelen organizmanın nekrotizan kabiliyetini arttırır. Uygun bir odakta yerleştikten sonra, F. necrophorum çoğalarak geniş koagulasyon nekrozuna neden olur (Nagaraja ve ark, 2005, Uzal ve ark. 2016).

Belirtiler, yangının nedeni ve kapsamına göre büyük ölçüde değişiklik gösterir. Özellikle kedilerde iştahsızlık görülebilir. Ağız kokusu ve salya akması kaudal stomatitis veya glossitiste yaygındır ve tükürük kanlı olabilir (Gracis 2015, Reiter 2014). Sunulan olguda da benzer şekilde salya akışı ve kanlı akıntı görüldüğü hayvan sahibi tarafından bildirilmiştir.

Hayvan, ağzına pençe atabilir ve ağrı nedeniyle ağız boşluğunu inceleme girişimlerine tepki verebilir. Bölgesel lenf dügümleri büyüyebilir. Kediler genellikle yiyeceklerine açlık içinde yaklaştıklarında bir "yaklaşma-kaçınma" davranışı gösterirler, ardından rahatsızlık beklentisiyle tıslar ve kaçarlar. Durum şiddetli ve uzun süreli ise, kilo kaybı belirgin olabilir (Reiter 2014). Ağız lezyonları olan bir hayvan, veteriner hekime tanısal bir zorluk sunar. Oral kavite vücuda açılan bir pencere olarak düşünülebilir, çünkü oral bulgular birçok sistemik bozukluğa eşlik eder. Oral dokular travma ve strese aşağıdaki yollardan biri veya birkaçı ile yanıt verir: hiperemi ile sonuçlanan vazodilatasyon, epitel hipertrofisi veya atrofisi, submukozal kanama ve infarktüs ile kapiller rupturu, ülserasyon ve nekroz (Arzi ve ark. 2008).

Love ve ark (1980) derialtı apsesi ve piyotorakslı kedilerden aldıkları örneklerde 4 farklı Fusabacterium türü izole ettiklerini ve bu türlerin $F$. necrophorum, F. russii, F. nauiyorme and F.nucleatum olduklarını bildirmişlerdir. Kedilerin "dövüş-yaralı" olarak adlandırılan subkutan apselerin ana kontaminasyon kaynağının ağız/üst solunum yolu olduğunu ifade etmişlerdir. Yapılan başka bir çalışmada (Talan ve ark. 1999) F. russi'nin köpek ve kedi florasının bir üyesi olduğu belirtilmiş ve insanlardaki enfekte köpek ve kedi ısırığı yaralarından izole edildiği bildirilmiştir.

Kedilerde glossitise neden olan önemli hastalıklardan birisi de Feline herpesvirus 1 enfeksiyonudur. Feline herpesvirus 1 öncelikle konjonktivit ve rinotracheitisi de içeren üst solunum yolu enfeksiyonuna neden olur. Glossitis, pnömoni, abort, keratit veya generalize enfeksiyon da bildirilmiştir. Kedi herpes virüsü ile ilişkili dermatit, evcil kedilerde nadiren görülmüştür. Lezyonlar multifokal, ülseratif, nekrotizan ve nötrofillerle karışık hücre tipi şeklindedir. Feline herpesvirus 1'in çitalarda kalıcı kutanöz ülserlere neden olduğu da bildirilmiştir (Hargis 1999). Yapılan bir çalışmada (Hargis 1999) Feline herpesvirus 1 enefeksiyonu saptanan kedilerde; epitel hücrelerinde nekroz, belirgin eozinofilik bir yang1 ve herpes virüs inklüzyon cisimcikleri ile ilişkili ülseratif, genellikle kalıcı, yüz dermatitisi veya stomatitis gözlendiği bildirilmiştir.

Sunulan olgudaki makroskobik ve histopatolojik bulguların değerlendirilmesi sonucunda dildeki değişiklikler nekrotik glossitis olarak tanımlandı. Bulguların değerlendirmeleri sonucunda saptanan nekrotik glossitisin nedeninin feline calcivirus veya nekrobasilloz ile ilişkili olabileceği düşünüldü. Fakat feline calcivirus enfeksiyonu ile ilgili (Hargis ve ark 1999, Reiter 2014) hayvanda başka bir klinik bulgu ve lezyonun gözlenmemesi üzerine nekrobasilloz olabileceği kanısına varıldı. Etken izolasyonu ve identifikasyonuna yönelik her hangi bir inceleme yapılamadı, fakat operasyon sonrasında alınan kitlenin histopatolojik incelemelerinde nekrotik yapılarla birlikte gözlenen değişiklikler nekrobasilloza yorumlandı. Bu değerlendirmeyi takiben kediye nekrobasilloza yönelik tedavi planlandı. Post operatif enfeksiyonlara karşı Ceftriaxone Sodium $20 \mathrm{mg} / \mathrm{kg}$ (i.v.)'a ilave olarak oral nekrobasillozis için Metronidazol 10 $\mathrm{mg} / \mathrm{kg}$ (p.o.) 10 gün süreyle günde bir kez verildi. Yapılan tedavi sonrasında hasta sahibi ile iletişime geçilerek hastanın genel durumu hakkında bilgi alındı. Hastanın genel durumunun iyi olduğu dilde herhangi bir lezyon şekillenmediği ve yeme-içmede herhangi bir sorun olmadığı öğrenildi.

Sunulan olguda, tümör şüphesiyle alınan kitlede nekrozlarla birlikte gözlenen değişiklikler sonucunda nekrotik glossitis tanısı konmuştur. Yer yer ülserli ve kanamalı görünümdeki kitleler genellikle tümöral oluşumlara yorumlanmaktadır. Fakat bu olguda da gözlendiği gibi, tümör gibi değerlendirilen benzer görünümdeki kitlelerde nekrotik-yangısel değişikliklerin de dikkate alınması gerektiği kanısına varılmışıtır. Benzeri durumlar için klinisyenlerin konuya dikkatini çekmek ve veteriner hekimliğe katkı sağlanması amacıyla olgunun sunulması uygun bulunmuştur.

\section{ÇIKAR ÇATIŞMASI}

Yazarlar, bu yazı ile ilgili herhangi bir çıkar çatışması olmadı̆̆ını beyan ederler.

\section{YAZAR KATKISI}

Tüm yazarlar eşit katkıya sahiptir.

Kongre Sunum Bilgisi: Olgu; sözlü ve özet olarak "International Congress on Biological and Health Sciences Congress. 26-28 February 2021, Afyon/TURKEY" de sunulmuştur. 


\section{KAYNAKLAR}

Anderson JG, Peralta S, Kol A, Kass PH, Murphy B 2017. Clinical and histopathologic characterization of canine chronic ulcerative stomatitis. Vet Pathol, 54(3):511-519. (doi: 10.1177/0300985816688754).

Arzi B, Anderson JG, Verstraete F 2008. Oral manifestations of systemic disorders in dogs and cats. Jour Vet Clin Sci.,1 (4): 112-124.

Çiftçi MK, Ortatatlı M, Erer H, Hatipoğlu F, Özdemir Ö 2021. Veteriner Sistemik Patoloji, I. Cilt, 5. Baskı, Nobel Tıp Kitabevleri, İstanbul.

Gelberg HB 2012. Alimentary System and the Peritoneum, Omentum, Mesentery, and Peritoneal Cavity, In. Pathologic Basis of Veterinary Disease, 5th Ed., JF Zachary and MD McGavin p.322-538, Elsevier, St. Louis, Missouri.

Görgül OS, Yavru N, Atalan, G, Bilgili H, Demirkan İ, Kılıç N, Sarıerler M, Taş A, Altuğ ME, Kibar M, Pekzan Z, Salci H, Kürüm B 2012. Veteriner Özel Cerrahi. Medipress, Malatya.

Gracis M 2015. Inflammatory Oral Diseases in Cats. World Small Animal Veterinary Association World Congress Proceedings, Bangkok, Thailand,15-18 May 2015,

Hargis AM, Ginn PE, Mansell JEKL, Garber RL 1999. Ulcerative facial and nasal dermatitis and stomatitis in cats associated with feline herpesvirus 1. Veterinary Dermatology. 10: 267-274. https://doi.org/10.1046/j.13653164.1999.00145.x

Jang SS, Hirsh DC 1994. Characterization, distribution, and microbiological associations of Fusobacterium spp. in clinical specimens of animal origin. J Clin Microbiol., 32(2):384-387. (doi: 10.1128/jcm.32.2.384-387.1994).

Love DN, Jones RF, Bailey M 1980. Characterization of Fusobacterium species isolated from soft tissue infections in cats. J Appl Bacteriol, 48(2):325-31. (doi: 10.1111/j.1365-2672.1980.tb01232.x).

Nagaraja TG, Narayanan SK, Stewart GC, Chengappa MM 2005. Fusobacterium necrophorum infections in animals: Pathogenesis and pathogenic mechanisms. Anaerobe 11: 239-246.

Reiter AM. 2014. Oral Inflammatory and ulcerative disease in small animals. MSD Manual. (https://www.msdvetmanual.com/digestive-system/diseases-of-the-mouth-in-small-animals/oralinflammatory-and-ulcerative-disease-in-small-animals) (26.09.2021)

Talan DA, Citron DM, Abrahamian FM, Moran GI, Goldstein EJ 1999. Bacteriological analysis of infected dog and cat bites. N Engl J Med; 340:85-92.

Uzal FA, Plattner BL, Hostetter JM 2016. Alimentary System. In. Jubb, Kennedy, and Palmer's Pathology of Domestic Animals. Ed. M.G.Maxie, Sixth ed., Elsevier, St. Louis, Missouri, p. 1-257 